DEVELOPING READING WORKSHEET BASED ON TASKBASED LANGUAGE TEACHING TO TEACH STUDENTS' READING COMPREHENSION FOR THE TENTH GRADE STUDENTS AT SMA NEGERI 3 MEDAN

AN ARTICLE

Submitted in Partial Fulfillment of the Requirements for the Degree of Sarjana Pendidikan

By

NURHANIFA LUBIS

Registration Number. 2163321036

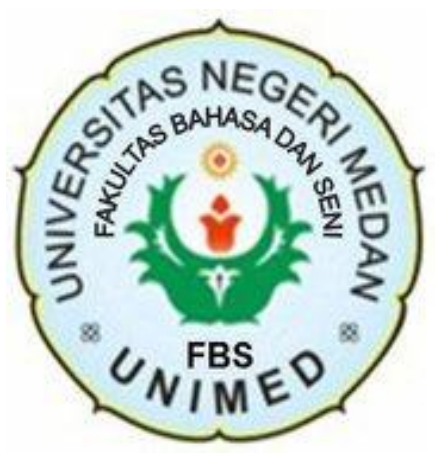

ENGLISH AND LITERATURE DEPARTMENT

FACULTY OF LANGUAGES AND ARTS STATE UNIVERSITY OF MEDAN 


\title{
DEVELOPING READING WORKSHEET BASED ON TASK- BASED LANGUAGE TEACHING TO TEACH STUDENTS' READING COMPREHENSION FOR THE TENTH GRADE STUDENTS AT SMA NEGERI 3 MEDAN
}

\author{
*Nurhanifa Lubis \\ **Dr. Anni Holila Pulungan, M.Hum
}

\begin{abstract}
Nurhanifa Lubis, 2163321036. Developing Reading Worksheet based on Task-Based Language Teaching to Teach Students' Reading Comprehension for Tenth Grade Students at SMA Negeri 3 Medan. A Thesis, English Educational Program, Faculty Language and Arts, State University of Medan, 2021.
\end{abstract}

The objective of this study was to develop reading worksheet based on taskbased language teaching to teach students' reading comprehension for tenth grade students at sma negeri 3 medan. This study was conducted by using Research and Development design through six stages; gathering data and information, need analysis, materials development, validating by experts, revising, and final product. The subject of the study was the tenth-grade students in SMA Negeri 3 Medan. The data were gathered by reviewing documents, conducting an interview with the English teacher, and distributing the students' needs analysis questionnaires to X MIA 2 consists of 35 students to get the students' needs. The interview and questionnaire results proved that the students needed reading worksheet based on task-based language teaching. The developed reading worksheets were validated by two experts which scored 3.77 and 3.87 on average. The scores approved that the reading worksheet based on task-based language teaching were very valid and suitable to use for the tenth-grade students in SMA Negeri 3 Medan. The result of the product was distributed to the students through bit.ly/TBLTworksheet

Key words: Development, Reading, Worksheet, Task-Based Language Teaching.

\footnotetext{
*Graduate Status

*** Lecturer Status
} 


\section{INTRODUCTION}

There are four skills in English that students need to acquire as the basis to be able to use English. These skills are listening, speaking, reading, and writing. Reading is one of the four language skills taught to learners of English. It cannot be learned quickly and effortlessly. Mickulecky \& Jeffries (2004) state that reading is very important since it can enhance students' general language skills in English; assisting students to think in English, enlarging students' English vocabulary, improving their writing, and it can be a good way to obtain about new ideas, facts and experiences. Therefore, on the basis of this opinion, reading skill has been viewed as something that can help students to enrich their insight in English language. Harmer (2003) also mentions thatthe ability to read texts in English is important as a bridge to understand the textbook. Reading is also one of the skills that is expected to be mastered by students in the 2013 curriculum.

There are many factors that can influence in English teaching and learning process, and one of them is the worksheet. Triantoro (2009) states that students' worksheet is a student guidance to conduct investigation or problem solving. It is also can be used to facilitate teacher in providing a practice and to enhance students' understanding. Therefore, worksheet can be used as a platform for students to know their ability in the learning process. Worksheet is also can be extremely helpful for teachers to know their students' progress in 
learning process, it can be a parameter whether a student has understood one particular topic or not.

In Indonesia, based on the 2013 curriculum worksheet should possess the stages of the approach that it used. So that it will identify students' understanding from the learning process in the classroom which also is based on certain approach. One of the approaches in teaching is task-based language teaching. Moore (2018) states Taskbased language teaching (TBLT) is a broadly defined approach to language teaching research and practice which uses task as a unit of analysis for research and practice in communicative language teaching. Yongliang \& Shipp (2009) state that the students will have a much more varied exposure to language with task-based language teaching. They will be exposed to a whole range of lexical phrases, collocations and patterns as well as language forms.

When it comes to reading, this is particularly important that the students can comprehend the text fully from thelexical phrases, collocations and patterns as well as language forms. It is in line to what Yongliang \& Shipp (2009) stated previously. Rozati (2014) claims that in all of these activities we are looking for one goal which is making students independent of the language to achieve that goal. It means that all of the tasks in task-based language teaching approach will initiate the students to synthesize the goal of their language learning independently. This can be shown from the stages of TLBT which 
include report, analysis and practice in which the students will explore the materials from the tasks.

Rozati (2014) states that the more task-based approach is studied the more necessity for sequencing of activities is observed. Therefore, the more worksheets use task-based language teaching approach the more stages of exercises that are done by the students will be observed.

However, based on the reconnaissance data from the observation that has been done by researcher to worksheets used in SMA Negeri 3 Medan, it was found that the worksheet used in SMA Negeri 3 Medan for the tenth grade does not provide more varied exposure to language compare to task-based language teaching.

The worksheet used in SMA Negeri 3 Medan does not possess any particular stages of language teaching approach. There is no particular approach used in the worksheet, the worksheet simply displaying some summaries of the materials and then directly followed by practices or tasks. This kind of worksheet is overly-simplified; students are expected to answer the questions written in the worksheet. This will not help the students to synthesize the goal of their language learning because this kind of worksheet is only used as a mean to score students not to make them understand the goals of their learning. Because it does not encourage the students to explore the goal of their language learning process independently because the students just 
simply answer the questions with no particular outcome of the activity. And also students are not free to use which grammar or vocabulary that they want because they simply choose the answer because most of the practices are multiple choices.

Halimah (2015) says that the use of worksheet is really crucial in teaching and learning process to increase understanding and comprehension of students, therefore a worksheet that can provide a platform for students to increase understanding and comprehension of students is highly needed. Che-Di Lee (2014) also shows that worksheets increase students' understanding and achievements and worksheets can be developed at conceptual basis for materials that are difficult to understand. Hence, the use of worksheet is really important in the process of learning as it can increase the students' understanding towards the lesson.

Shabania \& Ghasemi (2014) say that learners who were taught reading comprehension through task-based language teaching (TBLT) outperformed those learners who were taught reading comprehension through other approach. Such a result can be justified by considering some outstanding characteristics about the nature of task based language teaching and its effectiveness in EFL contexts. Task-based approach is a powerful and advancing learning method. It promotes learning language knowledge and training skills in the process of performing tasks. Teachers are both instructors and guides. Similarly, learners are both receivers and main agents. It is via TBLT that 
learners will master how to make full use of their own communicative abilities to shift from L1 to the target language. It presents a chance for them to learn cooperatively and interactively. Therefore TBLT is a really helpful approach in which it can advance the learning method.

However, current existing worksheet cannot really provide students with such benefits. It is only a matter of answering the questions provided in the worksheet. It cannot explore students' ability to make full use of their own communicative abilities in language. The existing worksheet does not give them a chance for students to learn cooperatively and interactively which will result that students cannnot explore more on thei language skills.

Therefore a more explorative worksheet is needed in SMA Negeri 3 Medan so that the students will be able to explore their language process independently and they will be able to synthesizethe goal of their language learning. Hence, researcher is intrigued to develop reading worksheet for the students of grade ten in SMA Negeri 3 Medan. This worksheet will be made based on the task-based language teaching approach and also will be made based on the needs of the students.

\section{REVIEW OF LITERATURE}

\section{a. Worksheet}

Belawati (2007: 3: 27) says that student worksheet is a teaching material that has been packaged in such a way so that 
students are expected to learn the teaching material independently. Students' worksheet is a series of task laid out in the form of questions. By answering these questions, students are able to master the materials they studied. Ladyawati (2009) states that students' worksheet is a series of task with questions that make students in working on get it done. Preparation of students' worksheet intended to provide ease of students in understanding the materials taught in the learning process. From the definitions above, it can be concluded that students worksheet is a way to assist and facilitate in the learning activities that will form an effective interaction between students and teachers and may increase the activity of students in the improvement of learning achievement.

Prastowo (2001: 204), worksheet is a teaching material printed in the form of sheets of paper containing materials, summaries and instructions of the implementation of learning tasks that must be performed by learners which refers to the basic competencies that must be achieved. In addition, the student worksheet contain several aspect such as title, basic competence, allocation time, brief information, instructions, tasks to perform and the report to make. It includes instructions, guidance and understanding questions so that the students could widen and deepen their understanding of the material being studied. Therefore, it can be considered that student worksheet is a source 
of learning which form of sheets containing briefly material, learning objectives, the instructions do the questions and a number of questions that must be answered by students. It can be concluded that student worksheet contain several aspects such as title, basic competence, allocation time, brief information, instruction, task to perform and the report to make.

Prastowo (2001: 208), there are five types of students' worksheet which are generally used by learners, namely:

1. Student worksheet that helps learners to find a concept

2. Student worksheet that helps learners to apply and integrate the various concepts that have been found

3. Student worksheet that serves as a study guide

4. Student worksheet that serves as a reinforcement

5. Student worksheet that serves as a practical guide

\section{b. Reading}

Nuttal (2002: 2) states that reading means a result of interaction between the writer's mind and reader's mind. It is the way how the reader tries to get the message or the intended meaning from the writer. In this process, the reader tries to create the meanings intended by the writer, the reader can get the message and the writer's meaning sense. 
Pang (2003: 6) reading is defined as understanding written texts. He says that reading consists of two related processes: word recognition and comprehension. Word recognition is defined as the process of getting how written symbols correspond to one's spoken language while comprehension is the process of making the meaning of words, sentences and connected text. He adds his statement that the reader who has background knowledge, vocabulary, grammatical knowledge, experience with text and other strategies can help them understand written texts.

\section{c. Recount Text}

Anderson (1997: 49) mentions that a recount is a piece of text retells past events, usually in the order in which they happened. It has a purpose in which it gives the audience a description of what occurred and when it occurred. Knapp and Watkins (2005: 223) also say that a recount is a sequential text that does little more than sequencing a series of events. It is the simplest type of narrative genre. A recount is different from a narrative text in terms of the problems in the sequence of events. Another view comes from Recount can be in the form of letters, newspaper reports, conversations, speeches, television interviews and eyewitness account. 
Anderson (1997: 53) states that a recount text has three main parts:

1. Orientation; It gives background information about who, what, where, and when.

2. A series of paragraphs; It consists of paragraphs which retell the events in the order in which they happened.

3. Re-orientation (optional); It is a paragraph that contains a personal comment.

In conclusion, a recount text tells the reader what happened in the past. It begins with an orientation which tells the reader who was involved, what happened, where this event took place and when it happened. Then, the sequences of events are described in some sort of order e.g. time. Last, it may be a reorientation at the end which summarizes the event.

Since each type has its own specific purpose, there are slight differences in each language features of the text. Generally, recount will focus on specific participants, the use of temporal sequence, the use of simple past tense, the use of action verbs (material process), and the existence of linking words to do with time (circumstances of time) and place. Normally, details irrelevant to the purpose of the text should be avoided. 


\section{d. Reading Recount Text}

Based on the syllabus, there are two standard competitions for recount text based on its language skills:

1. Menangkap makna secara kontekstual terkait fungsi sosial, struktur teks, dan unsur kebahasaan teks recount lisan dan tulis terkait peristiwa bersejarah

2. Menyusun teks recount lisan dan tulis, pendek dan sederhana, terkait peristiwa bersejarah, dengan memperhatikan fungsi sosial, struktur teks, dan unsur kebahasaan, secara benar dan sesuai konteks

As can be seen from the first standard competency, it demands the students to be able to catch the meaning. Looking at it from the language skill perspective, it is in line with the receptive skills which are Reading and Listening.

Based on first standard competency, it is also demanded the students to be able to catch the contextual meaning. As recount text is a text that retells a past event, Reading and listening involve receiving information and so they are called the receptive skills. Speaking and writing are known as the productive skills because they involve producing words, phrases, sentences and paragraphs. most of the contextual meanings will circulate around the specific or general information about the past event. Hence, it can be concluded 
that reading recount text is a skill which functions to find out meanings regarding specific and general information about the past event from the recount text.

\section{e. Task-Based Language Teaching}

Richard and Rodgers (2001, p. 223) define TBLT as follows, "TBLT refers to an approach based on the use of tasks as the core unit of planning and instruction in language teaching." This means that in the implementation of TBLT learners are mainly presented with a task or problem to solve. Task Based Language Teaching (TBLT) has been a recent expansion of Communicative Language Teaching (CLT) and has become a popular method to use to teach second language communicative acquisition (Dailey, 2009). According to Ellis (2003, p. 65), “TBLT is mostly about the social interaction established between learners as a source of input and means of acquisition, and involves the negotiation of meaning, communication strategies, and communication effectiveness".

Willis (1996) suggests a model for the use of TBLT in the classroom. This consists of:

1. Pre-task activity

An introduction to topic and task- in this stage the teacher introduces and defines the topic and the learners engage in activities that either helps them to 
recall words and phrases that will be useful during the performance of the main task or to learn new words and phrases that are essential to the task.

2. Task cycle

Task cycle consists of Task > Planning > Report. Here the learners perform the task (typically a reading or listening exercise or a problem-solving exercise) in pairs or small groups. They then prepare a report for the whole class on how they did the task and what conclusions they reached.

3. Post-task

The final stage is the language focus stage, during which specific language features from the task are highlighted and worked on. Feedback on the learners' performance at the reporting stage may also be appropriate at this point.

The main advantages of TBLT are that language is used for a genuine purpose, meaning that real communication should take place, and that at the stage where the learners are preparing their report for the whole class, they are forced to consider language form in general rather than concentrating on a single form (as in the PPP model). 


\section{RESEARCH METHODOLOGY}

The research was conducted by using Educational Research and Development (R\&D) method. Borg and Gall (2003: 569), Educational Research and Development (R\&D) is an industry-based development model in which findings of research are used to design new products and procedures, which systematically field-tested, evaluated, and refined to meet the specifies criteria of effectiveness, quality or similar standard.

\section{DATA ANALYSIS, FINDINGS AND DISCUSSION}

\section{A. The data}

In qualitative research, collecting the data mostly is done in participant observation, depth interview, and documentation. In correlation with this study, the researcher will use the questionnaire and interview as the instruments of data collection. The questionnaires will be developed based on the theory proposed by Hutchinson and Waters (1987) and Nunan (2004). Interviews will be carried out to the teacher teaching in class in order to derive the suitable materials. To comply with the questionnaires, interviews also will be conducted to the students at SMA Negeri 3 Medan.

\section{B. Data Analysis}

The analyzed data is the results of students' need analysis and existing materials from the hand book used for the tenth-grade students during the process of teaching and learning at SMA Negeri 3 Medan in order to plan the proper worksheet needed by the students. 
The data was attained through the theory of Creswell (2014). The data was analyzed through these following steps:

1. Organize and prepare the data for analysis. In this research, this step involves obtaining the syllabus, textbook, lesson plan, and existing reading worksheet, conducting interviews, and distributing the students' need analysis questionnaire.

2. Investigate the data. This step includes analyzing all the collected data prepared in the first step, transcribing the conducted interviews, and gathering the distributed questionnaire.

3. Coding. Coding is the process of developing data from the description and organizes the meanings into clusters of themes.

4. Interpretation. This step elaborates on how the description and cluster of themes will be represented in the research.

5. Confirmation. In this phase, the researcher will confirm the interpretations by matching them with the percentages on the clusters.

6. The last step is the presentation which will have the researcher write an inclusive description of the analysis as the result.

\section{Discussion}

This study aims to develop reading worksheet based on taskbased language teaching to teach students' reading comprehension for 
tenth grade students at SMA Negeri 3 Medan. The worksheet was developed since based on the preliminary data collected from an interview with an English teacher in SMA Negeri 3 Medan, there had been no worksheet based on task-based language teaching nor worksheet that can explore students' ability in comprehending a written recount text used in the teaching of recount text in the school. Meanwhile Chappell and Craft (2009) state that student worksheet is part of the teaching materials that can be used to develop thinking skills, asking and answering questions, making connections and assessing the improvement in learning outcomes of students.

A needs analysis was conducted in order to create a digital game that would be applicable and fit the students' settings. The needs analysis was meant to find out both the target needs and learning needs of the students. Target needs covered goal, necessities, lacks and wants of the students. Meanwhile, the learning needs covered the learning input, procedures, settings, and learner's role.

After getting the information about the students' needs, researcher started to design and develop the worksheet to fit with the students' settings.

Next step was validation. Two experts were appointed as the validators for this product. The first expert was Dr. Isli Indah Iriani Pane, S.Pd., M.Hum who is a lecturer in English and literature department in UNIMED, and the second expert was Ruwaida Sulaiman, S.Pd., M.Hum who is an English teacher in SMA Negeri 3 
Medan. The first expert's average score is 94.4, meaning that the product is valid, and the second expert's average score was 96.8, meaning that the product was very valid to be used.

There were also some suggestions given by the first expert which were to put the source of citation of the recount text, preferably the recount text is the one who discuss about historical events in North Sumatera, to input pictures in the worksheet and to change the options of the questions to be synonym instead of the literal indonesian translation

After revising the product according to the suggestions that had been given, the worksheet was finalized and complete. The worksheet itself is now ready to be used. It can be accessed on bit.ly/TBLTWorksheet.

\section{CONCLUSION AND SUGGESTIONS}

\section{A. Conclusion}

The researcher concludes that there had been no workshet based on task-based language teaching used in the teaching of recount text in SMA Negeri 3 Medan. The students found it difficult to produce a recount text and they wanted to be more active in learning recount text. They also wanted to use a worksheet that can help them to explore their ability in comprehending a written recount text. Hence, researcher got intrigued to develop a worksheet that can be used to teach recount text for these students.. There were 4 aspects that were judged by the validators which were linguistic, process, 
product and content, and layout. The average score by the first validator was 94.4 which mean that the worksheet is very valid, and the average score by the second validator was 98.6 which mean that the worksheet is very valid.

\section{B. Suggestions}

In line with the conclusion above, some suggestions are recommended as follows:

1. It is suggested that the newly developed reading worksheet based on task-based language teaching should be applied by the English teacher to accommodate the process of teaching and learning listening of recount text for the tenth-grade students in SMA Negeri 3 Medan.

2. It is suggested that the English teacher should be more responsive to the need of the students, teacher also should be able to provide worksheets that can hone students' higher-order thinking skill and reading comprehension.

3. Due to limited time, this research only develops reading worksheet for the recount text genre. Therefore, it is expected to other researchers to develop reading worksheet for other genres and other grades. 


\section{REFERENCES}

Anderson, M., \& Anderson, K. (1998). Text types in English (Vol. 3). Macmillan Education AU.

Belawati. 2007. Pengembangan Bahan Ajar. Jakarta: Universitas Terbuka.

Brown, H. Doughlas. (2004). Language Assessment Principle and Classroom Practice. San Fransisco:Pearson Education, Inc.

Brown, H. Douglas. (2001). Teaching by Principle: and Interactive Approach to Language.

Brown, H. D. (2000). Principles of language learning and teaching (Vol. 4). New York: Longman

Chappell, K., \& Craft, A. (2009). Creative Science Teaching Labs: New dimensions in CPD. Thinking Skills and Creativity, 4, 44-59. http://dx.doi.org/10.1016/j.tsc.2009.01.001

Darmodjo, H. \& Kaligis. J. R. E. (1992). Pendidikan IPA II. Jakarta: Depdikbud.

Derewianka, B. (2015). Teaching Writing in Today's Classroom: Looking back to looking forward. (pp. 69-86). Norwood, Australia: Australian Literary Educators' Association. 
Ellis, R. 2003. Task-based Language Learning And Teaching. Oxford: Oxford University Press.

Gall, G., \& Gall, J. P. Borg.(2003). Educational research: An introduction. Longman Publishing

Halimah, Nurul. (2015). Developing Reading Worksheet For The Eight Grade Students Of MTS Raudhatul Jannah Palangka Raya, A Seminar Paper Research Presented to the Undergraduate Faculty, The State Islamic Institute Of Palangkaraya. Available online at http://digilib.iainpalangkaraya.ac.id/262/ 